\title{
The God of the Oppressed and the Politics of Resistance: Black and Dalit theologies of liberation
}

\begin{abstract}
Ankur Barua
Contemporary research in liberation theologies across the world has often ignored certain parallels between the ways in which theologians from the Black communities in the USA, South Africa and other places, on the one hand, and Dalit groups in India, on the other, have struggled with a dialectic between the retrieval of subjectivity within political spaces inflected by 'race' and 'caste' and the opposition to these essentialist categorizations. This dialectic between the need to operate within domains structured by these classifications and the Biblically-informed hermeneutical strategy of opposing these very orderings is one that is also reflected in a certain postmodern perplexity.

The alleged fading away of the meta-narratives of post-Enlightenment Europe, much touted by various strands of postmodernist thought, has received an ambivalent response from groups involved in forging networks of solidarity such as feminists, socialists and so on. On the positive side, a complex of material, cultural and ideational forces are lauded for having played a crucial role in the 'problematization' and the dismantling of the essentialist binaries that were constructed by forms of knowledge which sought to draw clear demarcations between the social identities of two blocs of humanity, whether men versus women, whites versus blacks, the colonisers versus the colonised, and so on. In strands of post-structuralism and feminist criticism, the emphasis heavily falls on the 'politics of difference' which revolves around the multiplication of histories and identities which had been consigned to the
\end{abstract}


margins by the 'discourses of modernity'. On the other hand, the rejection of the decontextualised and gender-blind legislative rationality of the Enlightenment associated with the self-determining Cartesian cogito has sometimes been replaced by an aesthetic celebration of fractured and fragmented selves. The prominence given to localities, marginalities and heterogeneities in various dimensions of post-colonial theory and cultural anthropology raises the vital issue of whether in the absence of the possibilities of objective self-representation we can develop forms of knowledge that can challenge systems of domination and provide the bases for political solidarity. Indeed, it has been argued that without the notions of autonomy and identity, even if they are realised only falteringly and contingently in contextualised locations, an enabling vision for the struggles of the oppressed to maintain some control over their daily existence cannot emerge (Benhabib 1992).

To be more specific: one the most daunting challenges that keeps on reappearing in the writings of various post-colonial theorists, cultural critics, anthropologists and feminists, is of traversing the conceptual terrain opened up by the Foucauldian perspective that subjectivity is an effect of shifting discourses of power, the postmodernist emphasis on decentredness, and so on, while making common cause with a variety of emancipatory and contestatory politics by recovering hidden histories, cultures, and identities and articulating the voices of the dispossessed (Said 1991). For instance, the critique of the notion of 'universal sisterhood' on the grounds that it is guilty of co-opting the diverse experiences of women suffering from oppression in various socio-cultural contexts and parading a certain parochial European understanding of feminism as the paradigmatic one has sometimes led to a mere proliferation of women's experiences that are rooted in national, ethnic, or cultural specificities. For some feminists at least, the response to these dilemmas is to construct a strategic alliance between postmodernism and the emancipatory goals of feminism, by providing a critique of both 
ethnocentric universalisms and relativisms that would essentialize women as carriers of dehistoricized traditions insulated from one another (Sinha, Guy and Woollacott 1999). Reflecting such a view, Nancy Hartsock (Hartsock 1990, 163) argues that we should hold on to the category of 'woman', through its numerous fragilities and redefinitions, and asks pointedly, 'Why is it that just at the moment when so many of us [women] who have been silenced begin to demand the right to name ourselves, to act as subjects rather than objects of history, that just then the concept of subjecthood becomes problematic?'

In this article, we shall explore some of the ways that Black and Dalit liberation theologies have engaged with this postmodern dialectic between founding movements of resistance on categories that are supposed to be 'essential' and between seeking to dismantle these very categories by historicizing them as contingent products and not natural kinds. On the one hand, their politics of resistance has been predicated on their specific Black or Dalit identities, while, on the other hand, the postulation of such identities has often been criticised for being essentialist and homogenizing. For instance, the hermeneutical privilege accorded to the experiences of oppression and deprivation has led these theologians to speak of a Black or a Dalit subject that would resist, through divine aid which is claimed to be on the side of the subjugated, the systemic injustices of white society or caste repression. However, such scriptural readings are sometimes critiqued for having set up oppositional identities such as black versus white, antagonistic caste groupings or conflicting classes, which, it is argued, have no ontological validity in the ultimate scheme of things as laid down in the Bible (Bonino 1983). In other words, the attempt to read the world through the cruciform humanity 
of a 'Black Christ' or a 'Dalit Christ' has to deal with the overall structure of Christian thought, in which adversarial identities based on race, class, caste, gender and so on, have to be located within the parameters of Biblical Christianity defined by the doctrines of creation, redemption and universal reconciliation. It would seem, therefore, that such patterns of 'theologies of liberation' have to steer clear of the Scylla of a postmodern-style dissolution of subjectivities in which the Black or Dalit identities are effaced in a 'raceless' or 'casteless' amorphousness, and the Charybdis of 'ontologizing' the experiences of Blackness or Dalitness in a manner that may re-entrench these binaries which arguably cannot be fitted into the Christian eschatological vision of the reconciliation of all humanity.

One of the key themes that we shall seek to highlight in the following sections is that the search for such concepts of identity need not imply an uncomplicated reversal to selfconstituting and self-sovereign Black or Dalit subjects; rather, the challenge is to develop categories, possibly drawn from scriptural exegesis, which will give the self a history which is necessary for its engagement in contestatory politics while deciphering and challenging the processes through which the self's contours are constructed. In our analysis of some Black and Dalit theologies, we shall seek to illuminate the distinctive ways in which they assert hitherto repressed subjectivities, through emphasising the capacities of Blacks and Dalits to become subjects of their own histories, while seeking at the same time to avoid ontological dualisms between sections of humanity, now fractured along the lines of race and caste. Black and Dalit theologies therefore share with Latin American liberation theologies the task of explicating in precisely what sense Biblical exegetes may speak of a 'preferential option' for the oppressed as they seek, guided by the light of the Gospel, to forge solidarities among the poor, the marginalised, and the exploited. Liberation theology emerged sometime in the 1970s as a distinctive mode of critical reflection on the Bible in the context of the grinding 
and dehumanising poverty of millions of Latin American people. Gustavo Gutierrez, one of its central figures, emphasises that the Christian 'preference' for the poor points not towards some exclusivity centred around them but to their condition as demanding immediate concern, and this is precisely how the God of all humanity, revealed in the Bible, loved the hungry and the oppressed. Recalling his earlier writings, Gutierrez (1988, xxv-xxvi) highlights this crucial point in the revised edition of his Theology of Liberation: History, Politics and Salvation: 'In the interests of truth and personal honesty I want to say that from the very beginning of liberation theology ... I insisted that the great challenge was to maintain both the universality of God's love and God's predilection for those on the lowest rung of the ladder of history. To focus extensively on the one or the other is to mutilate the Christian message'.

Along these lines, Black and Dalit patterns of theologies of liberation, as we shall note, usually hold together a vision of Christ specifically as the liberator of those who suffer from various forms of dehumanization in the 'Egyptian captivity' of white racism or caste-Hindu society with an affirmation of the common destiny of humanity. While the set of beliefs, values and institutionalised practices referred to as 'racism' and 'casteism' would seem to be distinct, in that the former divides human beings into groups based on their phenotypical traits, and the latter on the basis of endogamy, occupation, ritual purity and so on, they both lay down similar discriminatory policies towards the groups which are believed to be worse off, whether biologically, intellectually or morally. Whether caste discrimination should be regarded as a form of racism, whether caste oppression is linked to distinctive religious and philosophical notions of Hinduism, and whether one can meaningfully speak of casteism outside the Indian context have been intensely contested matters among anthropologists and cultural theorists. For instance, Gerald D. Berreman (1960) argued for a broader construal of 
'caste', viewing it as a system of hierarchically organised endogamous groups whose membership is hereditary and permanent, which would allow it to be compared to other forms of social stratification which lay down strict rules relating to segregation. More recently, during the World Conference Against Racism (WCAR) which took place in Durban in 2001 certain Dalit groups argued that caste discrimination should be recognized as parallel to race discrimination, though the dominant view was that race is connected to biology and caste to social system, so that the two forms of oppression cannot be compared (Visweswaran 2010). However, some theorists have argued that while biological difference is a prominent maker of race, we should view race as a social construct, maintained and transformed through specific socio-historical forces, which relates inequalities and differentiations to ascriptive physical and cultural factors. These forms of 'cultural racism', where the emphasis is placed not on biological heredity but the alleged insuperability of cultural differences, are arguably present on the Indian scene where boundaries, stereotypes, residential segregation and endogamy are often enforced between upper-caste Hindus and the Dalits (Baber 2004).

Against such a background of institutional oppression, Black and Dalit theologies attempt to forge subjectivities that can exercise agential power to overcome it, and viewing Christ himself as the paradigmatic figure of the oppressed, they regard his subjugation to the powers of his day as the hermeneutical key for exploring the ways in which divine power is at work in overcoming the forces that lead to dehumanization. Our discussion so far should have made clear the precise challenge faced by proponents of Black and Dalit theologies: to utilise the categories that the masters have imposed upon the oppressed, while at the same time to dismantle the masters' vocabulary in order to point towards a vision of universal reconciliation centred in Christ. In the following sections, we shall discuss how, in common with their Latin American counterparts, they seek to revitalise the often obscured themes of 
radical protest and eschatological hope that have been present in the Christian traditions down the centuries. InThey have struggled with the divine dialectic in the Biblical God's dealings with humanity: on the one hand, the canon of Scripture seems to indicate that God has an 'exclusivist' concern with the remnants, the fringes and the margins, but, on the other hand, it also sounds the note of an 'inclusivist' reconciliation centred in the Lord of all humanity (Rowland 1988).

Dalit Theologies: protest movements against Brahminical orthodoxy and universalist goals of reconciliation

'Dalit', which literally means 'broken', 'ground' or 'suppressed', is an expression of selfrepresentation used by groups which were earlier classified in British India as 'untouchables' or 'depressed classes'. Dalits stand outside the traditional four-fold hierarchical division (varnashrama) of classical Hindu society into Brahmanas, Kshatriyas, Vaishyas and Shudras. This mythical categorization, derived ultimately from the Rig Veda X, 90, was the basis for the subsequent emergence of numerous castes (jatis) which are hierarchicallyranked endogamous groups associated with certain food practices and occupations (Quigley 2004). Various theories have been put forward concerning the 'origin of the Dalits' such as their emergence through the admixture by way of inter-marriage between the four varnas, their socio-economic oppression by the predominant classes, and their segregation, physical and ritual, through the operation of the principles of purity and impurity. In several parts of the country, they remain towards the bottom of the economic ladder, dependent on the higher castes for their living either as landless labourers or as performing ritually polluting tasks such as sweeping streets and officiating as funeral priests (Webster 1992). Empirical studies reveal that the classical ideas of varnashrama feed into a hierarchical system, operated by the dominant Brahmanical codes of purity and status, which aggravates the Dalits' lack of 
political power, their social exclusion and disabilities, and their economic impoverishment. There is an intimate feedback between the socio-economic bases of destitution and landlessness that the Dalits suffer from, their social experiences of servility, seclusion, and fear, and their internalization of their low status which often manifests itself in low selfesteem, desperation, and loss of identity (Stanislaus 1999).

Against this background, a crucial component of the agenda of Christian Dalit liberation movements has been to develop theological visions that will utilise local languages, idioms, myths, symbolic patterns and cultural forms of the Dalits in order to give expression to their anguish, their hopes and their triumphs, and to their faith in a God who is present in the midst of their subjugation and who will yet raise them up from their bondage (Massey 1997). One of its central aims is to develop new self-understandings of 'Dalitness' in terms of their pride in being the carriers of distinctive histories and cultures: 'Dalit is dignified' (Prabhakar 1998, 211). A.P. Nirmal, a Dalit Christian theologian, writes that Dalit theology, which stands in radical opposition to 'Brahminic theology', is produced by the Dalits themselves to express their protest against centuries of domination and articulate their search for liberation. Therefore when a non-Dalit asks what is specifically Christian about this theology, the response would be that it is the 'methodological primacy' given within it to the experiences of Dalitness that makes it Christian. He backs up this claim with the theological affirmation that the Triune God is on the side of the Dalits and not of the non-Dalits who have been the oppressors of the former (Nirmal 1998). Indeed, for a Dalit theology, 'pathos is the beginning of knowledge', for it is through their own pain that individuals come to know God who, in Christ, participates in human suffering (Stanislaus 1999, 183). Quoting Deuteronomy 16:512 which records the narrative of the Jewish people's enslavement to the Egyptians and their subsequent Exodus, under the mighty hand of God, out of their 'affliction, toil and 
oppression', Nirmal writes that Dalit Christians too have undergone a liberating Exodus from Hinduism onto the hands of Jesus Christ. They have recognised the Dalitness of Christ himself who had identified himself with the Dalits of his day such as the tax-collectors and the publicans (Mark 2: 15-16), who had loved the Samaritans, the Dalits of the Israel of his times, and who is today present with the Dalit Christians in India in their everyday struggles. As the 'Son of Man' who came into this world not to be served but indeed to offer his life as a ransom for many, Jesus, 'the Prototype of all dalits', encapsulated all the experiences of mockery, humiliations, and suffering that Dalit Christians have had to undergo (Nirmal 1998, 227).

The theme of the cruciform nature of Dalit experience, however, raises the vital question of whether the situation of Dalitness is regarded as possessing some sort of normative priority in interpreting the Bible and formulating Christian doctrine, a critical issue that, as we shall see, emerges also in discussions of Black theology. In some strands of Dalit literature, the emphasis falls on reclaiming the pristine historical condition of the Dalits who are supposed to have been overpowered by Brahmanical invaders. A key component of these Dalit visions of the past is the theory of a group of Aryans who spoke (Vedic) Sanskrit and who entered (modern day) India from the north-west, put forward by British Orientalists and ethnographers, and soon appropriated in a variety of ways by the colonial administrators, nationalist leaders, Theosophists and leaders of the Dalits. The textual evidence for this migration was believed to be present in the references in the Rig Veda to clashes between the aryas and the dasas, this aggression being taken as a support for the claim that a group of fair-skinned Aryans had invaded northern India by subjugating the dark-skinned original peoples. Jyoti Phule (1827-1890), a key figure in this context, wrote that before the Shudras were conquered by the alien Aryan Brahmanas, they had lived in a 'golden age', possessing 
their indigenous cultures, and this catastrophic event which led to centuries of their servility was to become a foundational theme in Dalit versions of the Indian past (Thapar 1999). The Dalits are consequently urged to reject the dominant understanding of 'indigenous' as archaic and retrogressive and replace it with the new self-understanding that they are the standardholders of a glorious past. Therefore, to challenge certain views of Dalit life as degraded, Christian Dalits have sometimes sought to assert the distinctiveness of its marginality over against the 'great tradition' of Hinduism rooted in the Sanskrit scriptures. In contrast to the 'Sanskrit religion' which is characterised as individualistic, brooks no protest against its sacerdotal ritualism, and divides the worshippers into separate castes, the 'Dalit religion' is put forward as one that is communitarian, incorporates an anti-clerical prophetic dimension, and allows access to all to the deity who is placed at the centre of the open-air worship place (Appavoo 1998).

While such re-imaginings of the past can be seen as a crucial move in the restoration of Dalits to their histories through indigenous cultural forms that had been denigrated by the Sanskritic tradition, they can become allied to nativist retrievals that occlude the exploitative nature of traditional cultural forms and ignore how identities are often constructed at the intersecting points of the multiple axes of class, ethnicity, gender and global economy. Thus a Dalit girl working in an Indian factory producing export goods suffers from economic exploitation like her other fellow-workers, but, in addition, she is also exposed to patriarchal domination and the specific forms of violence directed against members of the untouchable community (Wielenga 2007, 55). In order to widen the base of Dalit resistance, Dalit literature and activism have therefore sought more universal and inclusive definitions of 'Dalitness' which are sensitive to the matrices of domination configured by class, gender and religion, whether or not these visualizations maintain a specifically Christian focus. One of 
the most significant Dalit movements in contemporary India is the neo-Buddhist revival associated with B.R. Ambedkar who at the time of his initiation into the Buddhist way on 14 October 1956 declared that the Buddhist Dharma, committed to social justice and the institutional liberation of human beings, was the best religion (Fitzgerald 2007). Ambedkar was highly critical of certain aspects of traditional Buddhism such as its 'other-wordly asceticism' as manifested in the Theravada Buddhism of South East Asia with its concern for the individual's liberation. More sympathetic to the Mahayana strand of classical Buddhism, he recontextualised certain key Buddhist concepts in ways that reflect this affinity: wisdom is the ability to think rationally without any demystification, compassion becomes the love of fellow-beings expressed through activities directed towards social justice, and the monk is simultaneously the social worker and the seeker after personal freedom. Rejecting belief in a personal God, 'revelation', 'salvation' (in the Abrahamic faiths) or 'liberation' (moksha in the Indic religious streams), Ambedkar argued that true religion is instead the exemplification of a rationality that cleanses the dross of sacerdotal ritualism and other-worldliness, and that underlies a political commitment to the restructuring of asymmetrical power relations between the different sections of the community. Though the rate of growth among Buddhists in India remained very low in the decades after Ambedkar's death, studies indicate that Buddhist conversion freed some of the lower castes from a sense of inferiority and the belief that their ill-treatment was somehow justified (Zelliot 1977). The Dalit Panther Movement emerged around this time in 1972, inspired by the US Black Panther Party which was an Afro-American revolutionary socialist organisation active in the 1970s. It adopted a broadbased definition of 'Dalits' to include the neo-Buddhists, working classes, landless and poor peasants, women and those who are subject to various forms of political and economic exploitation. These Dalit movements often have a militant thrust and sternly criticise attempts at a peaceful resolution of the contradictions through which caste-oppression is sustained. 
The Dalit Panthers clearly struck the revolutionary note by declaring: 'We do not want a little place in the Brahmin Alley. We want the rule of the whole land, we are not looking at persons but at systems and change of heart ... liberal education etc. will not end our state of exploitation. When we gather a revolutionary mass, rouse the people, out of the struggle, the giant mass will become tidal wave of revolution' (Singh 2007, 173). The call is for the oppressed to affirm their own selfhood and put forward their culture and consciousness in public spaces, if necessary through violent conflict with the oppressors (Illaih 1996).

However, most strands of Dalit Christian theology, insofar as they emphasise the goal of universal reconciliation centred in Christ, have resisted a division of the world into two neatly polarised ('Manichaean') groups of the 'noble Dalits' and the 'evil non-Dalits'. Rather, they insist that the God of love and justice, who is the Lord of all, has often been distorted into an 'idol' by the dominant groups in order to legitimise their authority and privileges over others. According to this universalist vision of the goals of Dalit theology, Christian Dalits should work towards the formation of an organisation that would enable the participation also of non Dalit Christians towards the end of building communities which would be completely devoid of hierarchical and repressive structures. Indeed, a 'Church of the Dalits' is sometimes put forward not exclusively for the Dalits but as one within which preference is given to all marginalised groups who have suffered from socio-religious oppression and who have now come together to forge bonds of solidarity with one another. In order to achieve liberation by attaining a true humanity, Dalits need a common identity, which will grow out of their shared experiences of ongoing suffering, economic, political and social. Citing the text, 'And the Word was made flesh and dwelt among us' (John 1: 14), James Massey writes that in Christ we encounter the incarnate God who became the poorest of the poor, and this divine identification with humanity provides Dalits with a model of solidarity with all human beings 
who might be suffering under oppressive institutions (Massey 1997). These fundamental concerns of Dalit theology, which sometimes broadly accept the tools of Marxist social analysis but emphasise the structural violence that the caste system inflicts on the Dalits, mark it as an 'Asian theology of liberation' which, it has been argued, affirms that in Jesus God has become the oppressed neighbour, so that the confession 'Jesus is Lord' has to be authenticated through a political struggle for the poor (Pieris 2004).

\section{Black Theologies: the Black God and the God of liberation}

Several of the key themes that we have noted in Dalit theologies - that the experiences of people in deprivation provide the context in which we encounter Christ, and that critical reflection on the text of the Bible should move us in the direction of the establishment of humane and just institutions - recur through strands of Black theologies. In both styles of reading the Bible, it is approached not primarily as an exercise in textual scholarship, but with a commitment to the marginalised and the oppressed, with the hope that such a shared reading carried out, as it were, at the foot of the Cross, will make the Biblical characters and events resonate within the experiences of the poor people. Forged within the crucible of suffering, these theologies of liberation seek to develop a dialectic relationship between faith and commitment to and solidarity with the poor and the marginalised. However, as in the case of Dalit theologies, once can discern a creative tension running through certain strands of Black theology between, on the one hand, an affirmation of the presence of Christ specifically in the experiences of the Black people and, on the other, the location of such theology within the bounds of Christian orthodoxy which does not admit metaphysical dualisms except the one between the Creator and the created. 
These topics and tensions characterise the work of James H. Cone, who is often regarded as one of the foundational figures associated with Black theology (Antonio 2007). Cone argues that Black theology is the form of theological reflection that emerges out of the experiences of oppression that Black people have suffered, and that by proceeding through a critical engagement with the text of the Bible seeks its relevance for their struggles against white racism. Cone writes that the 'prior unity' that underlies all Black Christians, irrespective of their denominational differences, is their common experiences of oppression, and because this must be 'the supreme test of truth' for their theological formulations, no anthropology or Christology which does not affirm the dignity of Black people and their quest for freedom must be accepted. By electing the Israelite slaves and by coming into the world as the Oppressed One, God has made the condition of all oppressed peoples as God's own, and Black theology therefore affirms the blackness of God so that liberation itself may be understood as the process of becoming black with God (Cone 1990). Indeed, Cone passionately claims that '[a]11 ideas which are opposed to the struggle for black selfdetermination or are irrelevant to it must be rejected as the work of the Antichrist' (Cone 1969, 120). Moreover, the primary audience of Black theology is not the white people for they possess minimal capacities for creatively responding to the brute realities of Black suffering; rather, it is a theology that speaks to and for the Black people by constantly reminding them that Christ, who was himself rejected and oppressed, has accepted the Black people and made them his own. Therefore, to the 'liberals' who claim that Christ is 'beyond race', Cone replies that for oppressed Blacks to think of Christ in these terms is not any more possible than the followers of Jesus in the first century could have thought of their master as non-Jewish. Racist values and stereotypes continue to pervade the white atmosphere even as these theologians speak of moving beyond race: Cone notes that the 'raceless' American 
Christ often turns out to have a light skin and blue eyes and that whites would be offended by the portrayal of Christ with African features.

Cone thus seeks to reminds us that theologising never happens in a socio-political vacuum, and given that theologians cannot completely transcend their social standpoint, their theological discourses, in this sense, cannot be 'purely' neutral or apolitical. Therefore, while he recognises that the Christian doctrine of God (logically) precedes anthropological doctrine so that 'God', 'whiteness' and 'blackness' cannot be three ontological categories, he also affirms: "This work ... seeks to be revolutionary in that "The fact that I am Black is my ultimate reality"...Therefore, if a higher, Ultimate Reality is to have meaning, it must relate to the very essence of blackness' (Cone 1969, 32-33). Criticising those Black theologians who, he believes, have simply adopted the theological tools and problems laid down by white theologians, he affirms a 'ghetto theology' arguing that only this can provide the Black people with a truly radical message (Burrow 1994). Indeed, Black theology is the 'survival theology' of the members of a community who have to grapple with the issues of life and death in a context that is implacably hostile to them, and consequently it must be couched in passionate language that emerges out of the depths of their agony (Williams 1972). Therefore, his theology revolves not around some 'abstract humanity' (unlike the case of 'passionless' white theology) but the concrete humanity of the oppressed Black people, and the truth that he seeks to articulate arises from his engagement with the inhumanities that are heaped upon them. Sharply criticising the appeal to a universal, ideal humanity, Cone writes: 'Oppressors are ardent lovers of humanity. They can love all persons in general, even black persons, because intellectually they can put blacks in the category called Humanity' (Cone 1990, 85). Cone here echoes the theme, often articulated in Latin American liberation theology, that whereas the primary challenge for theologians in post-Enlightenment European 
contexts is that of developing responses to individuals with secularist modes of thought and practice, that is, the 'non-believer', Latin America presents a rather different challenge of preaching the Gospel to poor, exploited and dehumanised individuals, that is, the 'nonperson' (Gutierrez 2007). Cone too argues that readings of Scripture should provide the Black people with the means to survive in a world permeated with white racism, for questions such as whether it is possible to have knowledge of God outside revelation and whether human existence has any significance in a world where 'God is dead' are white problems and do not speak to the experiences of the Black people (Cone 1990, 63). The crucial question instead is how to account for the claim that Jesus saves to Blacks who continue to suffer at the hands of white fellow Christians (Nicolson, 1990). Black theology is therefore specifically formulated from the contextual perspective of an oppressed people - theological statements must cohere with, and also support, the goals of liberation of the Black people from the institutions that perpetuate racism (Fields 2001).

Cone produced some of his ground-breaking texts on Black theology against a dense sociopolitical background in which Black movements had adopted somewhat conflicting positions regarding the means to overcome white oppression, ranging from the mainstream Civil Rights movement of Martin Luther King through the more militarist Black nationalism of Malcolm X, the separatist strands of Afro-centrism to the cultural nationalism of poets and singers who created a Black aesthetic (Van DeBurg 1992). Some of them, such as Black Power in the 1960s and the 1970s emphasised Black racial pride, autonomy and selfdefinition, encapsulated in the motto 'Black is beautiful', and sought to develop institutions that would promote the collective interests of Blacks. Black Power was, in fact, a set of heterogeneous ideologies and not all of them favoured Black separatism: while the Nation of Islam violently rejected any integration with whites, who were denounced as the 'blue-eyed 
devils', the Black Panther Party adopted a Marxist standpoint and viewed itself as a Leninist vanguard party that would take the lumpen-proletariat of America towards freedom (Ogbar 2004). Another important strand in these responses to white racism was the Négritude or panAfrican movement associated with figures such as Aimé Césaire and Léopold Senghor, which, while stressing the primacy of Black experience as the starting point of critical reflection, usually aimed at universalist goals of reconciliation with the oppressors. It emphasised the collective experiences of Blacks under colonialism and sought to reclaim 'blackness' as a positive term which now stood for valorised African values, histories and cultures in opposition to the degenerateness of a Europe which was charged with having sunk into savagery. Thus Césaire writes that Négritude embodied the 'violent affirmation' against writers of world history who treated the Black heritage as an archaic relic that had made no contributions to humanity that there was a 'black civilization spread throughout the world' (Césaire 1972). Though some strands within the movement rejected any reconciliation with the west, Senghor understood Négritude not only as the positive valuation of African traditions and beliefs but as the basis of a relational philosophy which would celebrate the dynamic aspects of reality. Indeed, Senghor held that Négritude, the awareness and the development of the cultural values of African Blacks, revolves not around negation but affirmation, and it must therefore through a creative appropriation of external influences evolve into a 'panhuman socialization'. By stepping into creative dialogues with 'white Africa' and subsequently with members of the other continents of the world, Négritude would seek to build the 'universal civilization' which would be a 'dynamic synthesis' of the cultural values of the peoples of the world (Senghor 1965, 98). Senghor was clear about the mythical status of Négritude, though he argued that in contrast to 'false myths' which breed division and hatred, Négritude was the self-definition of a group of people who had become aware of their situation in the world. 
The emphasis on the self-affirmation and self-determination of the Blacks, whether this is carried out through non-violent civil disobedience, military resistance or separatism, is echoed and developed in distinctive ways by Black theologians. Along with them, Cone grapples with issues such as whether the claim that God is specifically concerned for the oppressed, the 'chosen people', conflicts with the Biblical view of the universality of divine benevolence, whether violence carried out by the oppressed goes against a Christian ethic, and whether the essence of the Gospel is reconciliation with the whites. A key theme which has been much discussed is whether, given the enormity of Black suffering, God can be acquitted of the charge of being a white racist, and whether responses to this suffering should be framed in terms of belief in a benevolent God or a strong humanist conviction that human beings have sufficient resources to deal with evil (Pinn 1995). In his contribution to these debates, Cone seeks to articulate a vision which is distinctly partisan in that God is not detached from the struggles of the Black people in their quest for dignity and self-affirmation, and which at the same time refuses to be drawn into a calculus of 'comparative martyrdom'. Black theology, as Cone sees it, is directed not to the denial of the suffering of other groups of people such as whites but to discerning the activity of God, who is not 'colour-blind', in guiding the oppressed towards their liberation. The contention therefore is not that 'blackness' is the appropriate term for all instances of oppression but that it 'is an ontological symbol and a visible reality which best describes what oppression means in America' (Cone 1990, 27). Drawing upon Tillich's conception of theological language as symbolic, he argues that 'blackness' must be understood, not as an affirmation that Blacks are the only people who suffer, but as a symbolic pointer towards the brutal oppression that people (including the Amerindians and the Mexicans) have experienced at the hands of the whites. Cone moves in the direction of affirming such a more universal definition of 'blackness' when he says: 
'Being black in America has very little to do with skin colour. To be black means that your heart, your soul, your mind, and your body are where the dispossessed are' (Cone 1969, 151). Nevertheless, Cone is clear that to oppose the images of a false God constructed by white supremacists, it is important to assert that the God who led the Israelites through the Exodus from Egypt is the God who is on the side of the oppressed blacks of contemporary America, and in this sense Black theology speaks of the 'blackness' of God. The oppressed stand in a special and favoured relation to God, and their liberation 'is a part of the innermost nature of God' (Cone 1990, 21). Therefore, insisting that Black theology takes the Pauline text, 'God was in Christ reconciling the world to himself' (2 Corinthians 5: 19), with seriousness, so that the dividing walls between all sections of the community have been broken down, Cone emphasises, however, that the true import of the biblical doctrine of reconciliation in this case is not that all blacks should be painted white but that whites should become able to accept the blacks qua blacks.

\section{Engaging with essential categories}

We have seen so far that theologies of liberation, despite their numerous contextual variations, sound a common note: the Biblical God is announced to be on the side of the oppressed and leading them towards freedom even in the midst of their present subjugation. Liberative praxis provides the context for Christian theology which sounds the call for continued engagement with, and elimination of, oppressive social systems and economic orders. The account of God's liberation of the Israelites in the Exodus, where the Israelites are often read as a type of the presently oppressed, therefore figures prominently in both Black and Dalit theologies. The term 'liberation' itself is understood not as an exclusive 
spiritualist concern with the 'salvation of souls' but to include socio-economic uplift, protection of civil liberties, challenging and dismantling of structures that cause poverty and injustice and so on.

However, as we have pointed out, these theologies have to grapple with a crucial dialectic that runs through attempts to hold together the specificities of the standpoint of the oppressed with the wider constraints of the Christian understanding of creation and redemption. On the one hand, they assert that the test of truth and the norm of doctrinal formulation is the experience of oppression, while, on the other, to the extent that they maintain distinctively Christian responses to such oppression, they affirm the priority of Christ to Blackness or Dalitness. The key question is therefore the viability and the scriptural legitimacy of appealing to deep collective selves, marked by race or caste, as the medium through which the Biblical message is channelled. It is argued that the mere fact that 'race' and 'caste' have now been shown to be not natural kinds but social constructions does not eradicate oppressive structures based on them, and that Blacks and Dalits approach Christ not so much as the 'universal man' but as the liberator whom they experience from within their contexts of oppression. As Jaroslav Pelikan has noted, Christ has been viewed through a number of images down the centuries varying with the socio-cultural contexts from within which human beings have sought to approach him, such as the 'King of Kings' in Constantinian Christianity, the 'true image of God' in the Byzantine Church, the 'ideal monk who rules the world' in the Medieval world, the 'Teacher of common sense' for Enlightenment influenced figures such as Jefferson and so on. In our times, the lives of Gandhi and Martin Luther King were significantly shaped by their perceptions of 'Christ as the Liberator' from oppression (Pelikan 1985). However, while such conceptions of a rediscovery of an essential unity have provided resources for anti-racist and anti-caste resistance, they have been critiqued from 
several viewpoints, which amount to the charge of using the categories of 'Black' or 'Dalit' in exclusionary and totalitarian terms. From a specifically Christian viewpoint, critics have raised concerns about the exclusiveness of liberation theologies, particularly the implication that only the oppressed people can form a true Christian community (Battle 2006, 107). For instance, J. Deotis Roberts has argued that reconciliation should be integrated into an account of liberation: though true reconciliation can take place only with the full liberation of the blacks from the oppressive structures of white racism, Black theology must seek reconciliation between black and white people, so that the two groups can meet as equals (Roberts 2005). Much of contemporary Indian Christian theologising too, sensitized by Dalit critiques to the complicity of religious systems in fostering an attitude of passivity towards injustices, speaks of the Church's commitment to the liberation of the oppressed and the establishment of social institutions, political structures, economic establishments and value systems which are informed by mutual love (Mattam 1997). While some influential movements within contemporary Dalit activism speak of militant struggle against the structures of caste-Hinduism, most strands of Christian Dalit theology strike a note of universalist redemption. Dalit theology, in this vision, will urge upon non-Dalits (whether or not they are Christians) that by perpetuating the institutions through which Dalits are currently oppressed, they are moving away from the 'authentic' humanity in which they were created by God, and act as a pointer towards the fullness of salvation which comes to all human beings through the redemptive grace of Christ (Massey 1997).

From a somewhat different angle, the construction of racialised or Dalitised subjects has been critiqued by feminist voices who have claimed that such homogenised identities render invisible the specific gendered oppression undergone by Black and Dalit women. 'Womanist' theology, developed by black female theologians, therefore critiques the triple 
forms of oppression, namely, sexism, racism and classicism and seeks to move black liberation theologies along more inclusive directions. Along these lines, T. Denean SharpleyWhiting challenges the male genealogies of Négritude and in her analysis of the gender politics within the movement shows that some marginalised black female intellectuals developed some of the key philosophical concepts which influenced the 'founding fathers' such as Césaire (Sharpley-Whiting 2002). Unlike first-generation black theology which usually took the black male experience as normative for the theological enterprise, and feminist theologies which did not adequately address issues of racism, womanist theology is put forward as a holistic reflection on the experience of being black and oppressed, where this oppression is now understood through the categories of gender, race and class (Hayes 1996). Dalit women too suffer from their locations along multiple axes of oppression: not only do they undergo victimization within the wider caste-society as Dalits, but they also often experience violence from Dalit men within the family (Pawade 1998).

In short, new voices within Black and Dalit theologies have criticised a romanticising quest for lost origins which seeks to recover realms of pristine experience or layers of uncorrupted tradition, whether in pre-Vedic times in India or Afro-centric value systems. Such 'reverse discourses' have been challenged more generally in post-colonial theory for replicating and perpetuating the coloniser/colonized distinction by attributing stable monolithic identities to both the poles of this and similar binaries that came into circulation at the colonial conjunctures (Parry 1996). Edward Said has argued, in the context of the discursive constructions of an 'Orient' that stands over and against the 'Occident', that the 'main intellectual issue' is this: 'Can one divide human reality, as indeed human reality seems to be genuinely divided, into clearly different cultures, histories, traditions, societies, even races, and survive the consequences humanly? By surviving the consequences humanly, I mean to 
ask whether there is any way of avoiding the hostility expressed by the division, say, of men into "us" (Westerners) and "they" (Orientals) ... When one uses categories like Oriental and Western as both the starting and the end points of analysis, research, public policy ... the result is usually to polarize the distinction - the Oriental becomes more Oriental, the Westerner more Westerner - and limit the human encounter between different cultures, traditions, and societies' (Said 1978, 45-6). The parallel question for our purposes is whether the invocation of Black and Dalit subjectivities locks the oppressed into the exclusionary polarities that were constructed by their oppressors who continue to dictate the terms of the contest. For instance, Victor Anderson (1995) has criticised the reification of race in some Black theologians and cultural theorists on the grounds that it produces a reactionary identity, based on ontological blackness, which is defined within the perimeters set by the ideology of white superiority. Racial identities based on such a 'victimology', it has been argued, only perpetuate self-hatred and stifle moves towards reconciliation and social mobility (Bradley 2010).

\section{Conclusion}

In response to such criticisms, the theological challenge is that of developing strategic solidarities among the oppressed, presently fractured along the lines of ethnicity, race, class and gender, by steering clear of postulations of a state of prelapsarian purity. We return, then, through several routes to the task of steering a path between nativist retrievals and postmodernist dissolutions that we had indicated in the initial sections of the essay. One instance of such an attempt can be seen in the work of M. Shawn Copeland who views black political theologies in very expansive terms as a Christian act of interpretation that strives to remove structural injustices, outlines the global market's subjugation of mind and body, detects covert forms of racism, sexism and imperialism, challenges modernity's exaltation of 
technical rationality, and so on. They should be animated, she argues, by a 'subversive piety' based on a radical hope in the God of freedom, which can sustain a long-term commitment to establishing justice for all humanity (Copeland 2004). In a world that continues to be marked by these fault-lines, Black and Dalit theologies have therefore raised the demand for selfrespect, security and dignity, and given new direction to liberation struggles which do not depend on the patronage from the dominant groups. Specifically in the case of Dalit movements, many contemporary Dalit writers have criticised the notion that the upper castes must bring about structural transformation on behalf of or in place of the Dalits, since the Dalits themselves are allegedly incapable of making any contributions in this regard. They have often viewed such upper-caste overtures as disguised attempts to co-opt their struggles against discrimination by inserting them into the caste hierarchy. James Massey points out that though some high caste Hindus are aware of the manifold brutalities and indignities suffered by the Dalits down the centuries, they do not have sufficient faith in the abilities of the latter to bring about radical changes in the institutional contexts within which these have been legitimised. Massey argues, however, that an act of true solidarity will be one where they reject the entire system which perpetuates this violence and come forward to work not for but with the Dalits (Massey 1997, 82).

In short, therefore, the 'blackness' or the 'Dalitness' of God can be located within an eschatological vision in this manner: while in the present order of things, they stand for the affirmation that Christ identifies himself with the oppressed, the 'chosen few', who are called upon to be co-labourers with Christ in the struggles against oppression, they also point to a supra-historical destiny where the oppressive structures dividing humanity will be broken down. Consequently, 'Black' and 'Dalit' are employed not as natural categorisations - for the eschatological horizons of the Bible do not admit any such ontological divisions - but as 
strategic devices for forging solidarity in the interim when these demarcations continue to be employed by the ruling powers for subjugating sections of humanity. While in naming God as 'Black' or 'Dalit', these theologies run the risk of setting up cultural idolatries, in thus arguing that divine providence works specifically through the fulcrum of a distinct oppressed people they can appeal to Biblical precedents of God's workings with humanity. As Oscar Cullmann once pointed out, redemptive history is based on the principle of representation, namely, the 'election of a minority for the redemption of the whole', and proceeds through two stages characterised by a progressive reduction and a progressive advance respectively. In the first movement of the old covenant, God chooses one community for the salvation of all humanity, and even within it a decreasing number of remnants in every generation until we come to the remnant, Christ himself. From the centre of the death and resurrection of Christ, the redeemer of the world, the divine plan of salvation moves outwards not, as earlier, from the many to the one, but now in the new covenant from the one to the many (Cullmann 1952). The crucial debate of course is over the theological reading of the contemporary Blacks and Dalits as the successors of historical Israel, and the claim that the symbolic affirmation of Christ as the oppressed can be the pivot of the liberation not only of the subjugated fragments of humanity but also of their oppressors. Pointing out that the poor people have been chosen by God because they suffer from various kinds of racial, class and gender based oppressions, Dwight Hopkins $(2002,192)$ goes on to argue: 'Because they are the majority of society and the world, when they are free and able to be full human beings, they provide a more favorable condition to alter nondemocratic structures experienced by the rest of the world. This includes freeing oppressor sectors on top who are the minority groups which exercise a disproportion of control in the global arena'. We may therefore understand the option for the oppressed as preferential - and not exclusive - and further, we are called upon to love them first not because they are morally superior but because God chooses to be 
revealed preferentially among them, and through them reveal the good news to all humanity (Goizueta 2004).

Our analysis of some influential moves within Black and Dalit theologies has highlighted the creative tension noted at the beginning of the essay, that between the focus on the distinctive forms of oppression in racist and casteist milieus as the launching-pad for developing Christian doctrine and the vision of a new common wealth built up in dialogue with people suffering from other forms of oppression, and ultimately with their oppressors. We have tried to show in this essay that much of the vitality of ongoing Black and Dalit theologizing derives from the attempts to keep this tension alive by simultaneously working through contexts of oppression and seeking to dismantle them. This is the tension, in the terms of Andrew Walls (1996), between the 'indigenizing' principle and the 'pilgrim' principle in Christian thought: on the one hand, Christ accepts and justifies human beings with the dense particularities of their specific socio-historical locations, but on the other hand, these communities, from distinct linguistic, ethnic, cultural and national backgrounds, are brought together in a wider family that transcends the distinctions of ethnicity and political allegiances. By placing the two principles in an eschatological setting, Black and Dalit liberation theologies could seek to avoid the perils of dissolution of identities and essentialised dichotomies: while the oppressed, presently marked by various experiences of dislocations and exploitation, have 'indigenised' Christ through the lens of Blackness and Dalitness, they, as the 'pilgrim' people, also hope for the eschatological fulfilment of the divine promise of emancipation from oppression.

\section{References}


Anderson, V. 1995. Beyond Ontological Blackness: An Essay on African American Religious and Cultural Criticism. New York: Continuum.

Antonio, E. 2007. Black Theology. In Cambridge Companion to Liberation Theology, Second Edition, ed. C. Rowland, 79-104. Cambridge: Cambridge University Press.

Appavoo, J.T. 1998. Dalit Religion. In Indigenous People: Dalits: Dalit Issues in Today's Theological Debates, ed. J. Massey, 111-21. Delhi: ISPCK.

Baber, Z. 2004. 'Race', Religion and Riots: The 'Racialization' of Communal Identity and Conflict in India. Sociology 38: 701-18.

Battle, M. 2006. The Black Church in America: African American Christian Spirituality. Oxford: Blackwell.

Benhabib, Seyla 1992. Situating the Self: Gender, Community and Postmodernism in Contemporary Ethics. Cambridge: Polity Press.

Berreman, G.D. 1960. Caste in India and the United States. The American Journal of Sociology 66: 120-27.

Bonino, J.M. 1983. Toward a Christian Political Ethics. London: SCM.

Bradley, A.B. 2010. Liberating Black Theology: The Bible and Black Experience in America. Wheaton, Illinois: Crossway.

Burrow, R. 1994. James H. Cone and Black Liberation Theology. Jefferson, N.C.: McFarland \& Co.

Césaire, A. 1972. Discourse on Colonialism. Translated by Joan Pinkham. New York: Monthly Review Press.

Cone, J.H. 1969. Black Theology and Black Power. New York: The Seabury Press.

Cone, J.H. 1990 [1970]. A Black Theology of Liberation: Twentieth Anniversary Edition. New York, Maryknoll: Orbis Books.

Copeland, M.S. 2004. Black Political Theologies. In Blackwell Companion to Political Theology, eds. P. Scott and W.T. Cavanaugh, 271-87. Oxford: Blackwell.

Cullmann, O. 1952. Christ and Time: The Primitive Christian Conception of Time and History. Translated by Floyd V. Filson. London: SCM.

Fields, B.L. 2001.Introducing Black Theology: Three Crucial Questions for the Evangelical Church. Ada, MI: Baker Academic.

Fitzgerald, T. 2007. Ambedkar, Buddhism, and the Concept of Religion. In Untouchable: Dalits in modern India, ed. S.M. Michael, 132-49. Delhi: Sage Publications.

Goizueta, R.S. 2004. Gustavo Gutierrez. In Blackwell Companion to Political Theology, eds. P. Scott and W.T. Cavanaugh, 288-301. Oxford: Blackwell.

Gutierrez, G. 1988 [1973]. A Theology of Liberation: History, Politics and Salvation. London: SCM.

Gutierrez, G. 2007. The task and content of liberation theology. In The Cambridge Companion to Liberation Theology, ed. C. Rowland, 19-38. Cambridge: Cambridge University Press.

Hartsock, N. 1990. 'Foucault on power: a theory for women?'. In Feminism/Postmodernism, ed. L. J. Nicholson, 157-75. London: Routledge.

Hayes, D. 1996. And Still We Rise: An Introduction to Black Liberation Theology. New York and Mahwah, N.J.: Paulist Press.

Hopkins, D.N. 2002. Heart and Head: Black Theology - Past, Present, and Future. New York: Palgrave.

Kancha Illaih, K. 1996. Productive Labour, Consciousness and History: The Dalitbahujan Alternative. In Subaltern Studies IX, eds. S. Amin and D. Chakrabarty, 165-200. Delhi: Oxford University Press.

Massey, J. 1997. Down trodden: the struggles of India's Dalits for identity, solidarity and liberation. Geneva: WCC Publications. 
Mattam, J. 1997. Mission as Social Concern - In Official Church Documents and Recent Missiological Literature. In Mission Trends Today, eds. J. Mattam and S. Kim, 55-75. Mumbai: St Pauls.

Nicolson, R. 1990. A Black Future? Jesus and Salvation in South Africa. Philadephia: Trinity Press International.

Nirmal, A.P. 1998.Towards a Christian Dalit Theology. In Indigenous People: Dalits: Dalit Issues in Today's Theological Debates, ed. J. Massey, 214-230. Delhi: ISPCK.

Ogbar, J.O.G. 2004. Black Power: Radical Politics and African American Identity. John Hopkins University Press: Maryland.

Parry, B. 1996. Resistance theory/theorising resistance or two cheers for nativism'. In Colonial discoursel postcolonial theory, eds. F. Barker, P. Hulme and M. Iversen, 172-96. Manchester: Manchester University Press.

Pawade, K. 1998. The Position of Dalit Women in Indian Society. In Indigenous People: Dalits: Dalit Issues in Today's Theological Debates, ed. J. Massey, 143-58. Delhi: ISPCK.

Pelikan, J. 1985. Jesus through the Centuries: His Place in the History of Culture. New Haven: Yale University Press.

Pieris, A. 2004. Political Theologies in Asia. In Blackwell Companion to Political Theology, ed. P. Scott and W.T. Cavanaugh, 256-70. Oxford: Blackwell, 2004.

Pinn, A.B. 1995. Why Lord?: Suffering and Evil in Black Theology. New York: Continuum.

Prabhakar, M.E. 1998. The Search for a Dalit theology. In Indigenous People: Dalits: Dalit Issues in Today's Theological Debates, ed. J. Massey, 201-213. Delhi: ISPCK.

Quigley, D. 2003. On the Relationship between Caste and Hinduism'. In The Blackwell Companion to Hinduism, ed. G. Flood, 495-508. Oxford: Blackwell.

Roberts, J.D. 2005. Liberation and Reconciliation: A Black Theology, Second Edition. Maryknoll, New York: Orbis Books.

Rowland, C. 1988. Radical Christianity: A Reading of Recovery. Cambridge: Polity Press.

Said, E. 1978. Orientalism. London: Routledge \& Kegan Paul.

Said, E. 1991. The World, The Text, and the Critic. London: Vintage.

Senghor, L. 1965. Prose and Poetry. Edited and Translated by John Reed and Clive Wake. London: Oxford University Press.

Sharpley-Whiting, T.D. 2002. Negritude Women. Minnesota: University of Minnesota Press.

Singh, K.P. 2007. Liberation Movements in Comparative Perspective: Dalit Indians and Black Americans. In Dalits in Modern India: Visions and Values, ed. S.M. Michael, 162-78. New Delhi: Sage Publications.

Sinha, M., Donna Guy and Angela Woollacott eds. 1999. Feminisms and internationalism. Oxford: Blackwell Publishers.

Stanislaus, L. 1999. The Liberative Mission of the Church among Dalit Christians. Delhi: ISPCK.

Thapar, R. 1999. Some Appropriations of the Theory of Aryan Race Relating to the Beginnings of Indian History. In Invoking the Past: The Uses of History in South Asia, ed. D. Ali, 15-35. Delhi: Oxford University Press.

Van DeBurg, W.L. 1992. New Day in Babylon: The Black Power Movement and American Culture, 1965-1975. Chicago: The University of Chicago Press.

Visweswaran, K. 2010. Un/common cultures: Racism and the rearticulation of cultural difference. Durham: Duke University Press.

Walls, A. 1996. The Missionary Movement in Christian History: Studies in the Transmission of Faith. Maryknoll, New York: Orbis.

Webster, J.C.B. 1992. A History of the Dalit Christians in India. San Francisco: Mellen Research University Press.

Wielenga, B. 2007. Liberation theology in Asia. In The Cambridge Companion to Liberation 
Theology, ed. C. Rowland, 55-78. Cambridge: Cambridge University Press.

Williams, P. 1972. James Cone and the Problem of a Black Ethic. The Harvard Theological Review 65: 483-94.

Zelliot, E. 1977. The Psychological Dimension of the Buddhist Movement in India. In South Asia: religious conversion and revival movements in South Asia in medieval and modern times, ed. G.A. Oddie, 120-44. London: Curzon Press. 
